\title{
Article \\ Chemical Composition and Thermogravimetric Behaviors of Glanded and Glandless Cottonseed Kernels
}

\author{
Zhongqi He ${ }^{1, *}$, Sunghyun Nam ${ }^{1}\left(\mathbb{D}\right.$, Hailin Zhang ${ }^{2}\left(\mathbb{C}\right.$ and Ocen Modesto Olanya ${ }^{3}(\mathbb{C}$ \\ 1 United States Department of Agriculture-Agricultural Research Service, Southern Regional Research Center, \\ 1100 Robert E Lee Blvd., New Orleans, LA 70124, USA; sunghyun.nam@usda.gov \\ 2 Department of Plant and Soil Sciences, Oklahoma State University, Stillwater, OK 74078, USA; \\ hailin.zhang@okstate.edu \\ 3 United States Department of Agriculture-Agricultural Research Service, Eastern Regional Research Center, \\ Wyndmoor, PA 19038, USA; modesto.olanya@usda.gov \\ * Correspondence: zhongqi.he@usda.gov
}

check for updates

Citation: He, Z.; Nam, S.; Zhang, H.; Olanya, O.M. Chemical Composition and Thermogravimetric Behaviors of Glanded and Glandless Cottonseed Kernels. Molecules 2022, 27, 316. https://doi.org/10.3390/ molecules27010316

Academic Editor: Mirella Nardini

Received: 3 December 2021

Accepted: 2 January 2022

Published: 5 January 2022

Publisher's Note: MDPI stays neutral with regard to jurisdictional claims in published maps and institutional affiliations.

Copyright: (c) 2022 by the authors. Licensee MDPI, Basel, Switzerland. This article is an open access article distributed under the terms and conditions of the Creative Commons Attribution (CC BY) license (https:// creativecommons.org/licenses/by/ $4.0 /)$.

\begin{abstract}
Common "glanded" (Gd) cottonseeds contain the toxic compound gossypol that restricts human consumption of the derived products. The "glandless" (Gl) cottonseeds of a new cotton variety, in contrast, show a trace gossypol content, indicating the great potential of cottonseed for agro-food applications. This work comparatively evaluated the chemical composition and thermogravimetric behaviors of the two types of cottonseed kernels. In contrast to the high gossypol content $\left(3.75 \mathrm{~g} \mathrm{~kg}^{-1}\right)$ observed in Gd kernels, the gossypol level detected in Gl kernels was only $0.06 \mathrm{~g} \mathrm{~kg}^{-1}$, meeting the FDA's criteria as human food. While the gossypol gland dots in Gd kernels were visually observed, scanning electron microcopy was not able to distinguish the microstructural difference between ground Gd and Gl samples. Chemical analysis and Fourier transform infrared (FTIR) spectroscopy showed that Gl kernels and Gd kernels had similar chemical components and mineral contents, but the former was slightly higher in protein, starch, and phosphorus contents. Thermogravimetric (TG) processes of both kernels and their residues after hexane and ethanol extraction were based on three stages of drying, de-volatilization, and char formation. TG-FTIR analysis revealed apparent spectral differences between Gd and Gl samples, as well as between raw and extracted cottonseed kernel samples, indicating that some components in Gd kernels were more susceptible to thermal decomposition than Gl kernels. The TG and TG-FTIR observations suggested that the Gl kernels could be heat treated (e.g., frying and roasting) at an optimal temperature of $140-150{ }^{\circ} \mathrm{C}$ for food applications. On the other hand, optimal pyrolysis temperatures would be much higher $\left(350-500{ }^{\circ} \mathrm{C}\right)$ for Gd cottonseed and its defatted residues for non-food bio-oil and biochar production. The findings from this research enhance the potential utilization of Gd and Gl cottonseed kernels for food applications.
\end{abstract}

Keywords: cottonseed; fourier transform infrared spectroscopy; glandless; scanning electron microcopy; thermogravimetric analysis

\section{Introduction}

Cottonseed is a major product of cotton (Gossypium spp.) crops after fiber harvest [1,2]. The current global cottonseed production is estimated at $42 \times 10^{6} \mathrm{Mg}$ annually [3]. Currently, cotton fiber accounts for $85-90 \%$ of the value of the crop while cottonseed accounts for the rest, a small share even though there are $150 \mathrm{~kg}$ of cottonseed produced for every $100 \mathrm{~kg}$ fiber ginned [4]. Cottonseeds can be utilized directly or further processed into five products, i.e., linter ( $8 \%)$, hulls $(27 \%)$, crude oil (16\%), meal (protein and carbohydrate, $45 \%)$, and waste $(4 \%)[4,5]$. Refined cottonseed oil is edible, and has been used in the food industry as a cooking oil or an ingredient in salad dressing, shortening, and mayonnaise, so it contributes currently to the major income of cottonseed processing $[4,6]$. However, the nutrient-rich whole cottonseed and its non-oil products cannot be used 
directly for human and other monogastric animal consumption, due to the presence of the toxic compound gossypol $\left[\mathrm{C}_{30} \mathrm{H}_{30} \mathrm{O}_{8}, 1.1,6,6,7,7\right.$-hexahydroxy-5,5-diisopropyl-3,3-dimethyl(2,2-binaphthalene)-8,8-dicarbaldehyde, or 2,2'-bis-(formyl-1,6,7-trihydroxy-5-isopropyl3 -methylnaphthalene] stored mainly in the pigment glands $[7,8]$. Gossypol not only can lead to liver damage and even fibrosis itself, but also can combine easily with the $\varepsilon$-amino group of lysine of protein fractions, resulting in a decrease of lysine activity, which makes lysine become the first limiting amino acid in nutrition $[9,10]$. Thus, research efforts have been made to produce a new type of cottonseed in which gossypol is present only in trace amounts so that the cottonseed and its value added products can be used for animal feeds and human foods [11-13]. To distinguish the two types of cottonseeds, the new type is called "glandless" (Gl) while the traditional type is called "glanded" (Gd) cottonseed (Figure 1). While there is plenty of research on characterization and utilization of Gd products $[2,14,15]$, research on $\mathrm{Gl}$ samples is quite limited. Generally, Gl protein-based adhesives have shown similar bonding performance as their Gd counterparts [16]. Both Gd and Gl kernels contained some bioactive ingredients and antioxidant activities [17-19]. However, peptide profiling indicated that there might be some differences in the distribution patterns of the storage proteins in Gd and Gl preparations, although more quantitative studies are needed $[9,20]$. Compared to soy protein, Gl protein isolate showed lower water-holding and oil-holding capacity but had similar gelation properties, elevated foaming capacity at high $\mathrm{pH}$ values, and greater emulsion stability [21]. With a trace content of toxic gossypol, Gl cottonseed is especially promising if processed for food applications, such as roasted nut-like products and cottonseed butter although no viable processing details have been reported [22,23]. Reyes-Jáquez et al. [24,25] formulated and evaluated Gl-meal/corn flour snacks by extrusion cooking. Shrimp feed with Gl cottonseed meal as a protein source was made by extrusion and its structural, rheological and calorimetric properties evaluated, showing the Gl meal-based shrimp feed is a reasonable option to decrease feeding costs [26,27]. Specifically, Gl cottonseed protein could replace up to $75 \%$ fishmeal protein in the diet of southern flounder without compromising its growth potential [28]. In other words, Gl cottonseed could be an inexpensive protein source for the commercial culture of southern flounder and other finfish species.

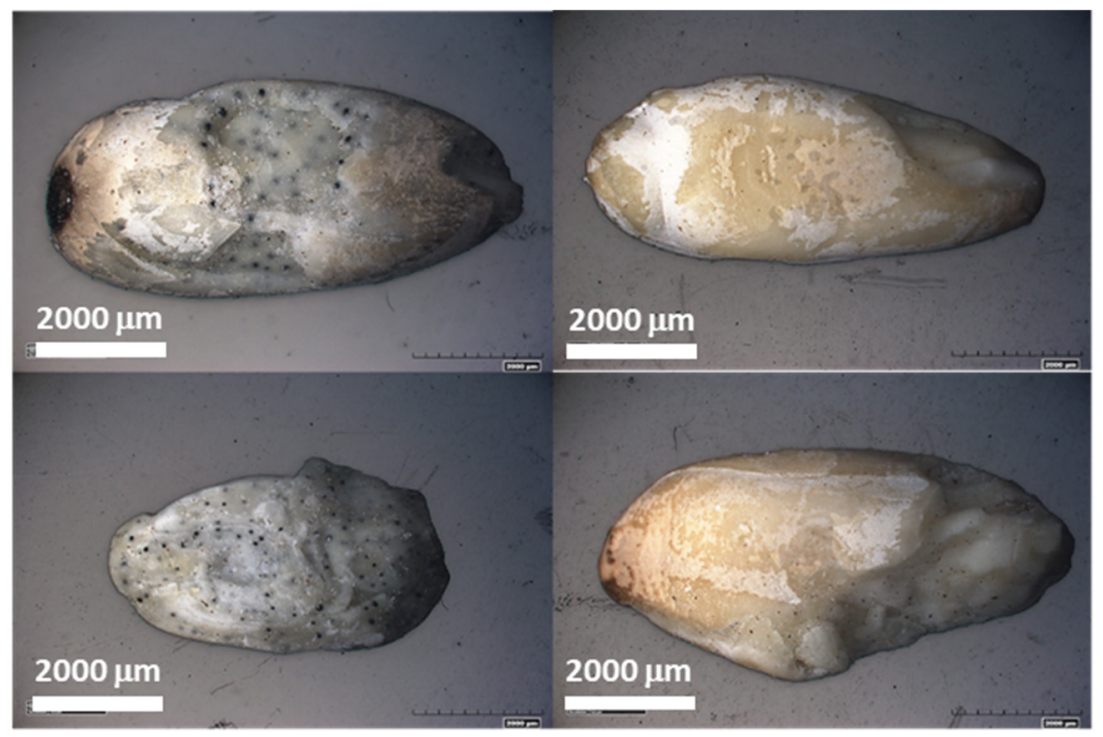

(A) Glanded cottonseed kernels

(B) Glandless cottonseed kernels

Figure 1. Images of glanded (A) and glandless (B) cottonseed kernels. The small black dots appearing on the kernel surfaces of sample (A) are the gossypol glands.

Fourier transform infrared (FTIR) spectroscopy is one of the non-destructive instrumental techniques widely used in applied cotton fiber, cottonseed, and other cotton biomass 
research [29-32]. Cottonseed-derived oil [33,34], protein [35,36] and carbohydrate products $[31,37]$ have shown different FTIR features. Specifically, FTIR intensities of 1665 to $1680 \mathrm{~cm}^{-1}, 1646$ to $1660 \mathrm{~cm}^{-1}, 1638$ to $1645 \mathrm{~cm}^{-1}$, and 1615 to $1637 \mathrm{~cm}^{-1}$ have been used to evaluate cottonseed protein's secondary structures ( $\beta$-turns, $\alpha$-helices, random coils, and $\beta$-sheets) [38-40]. Sun et al. [41] used FTIR to detect the chemical and conformational changes between transgenic cottonseeds and their non-transgenic counterparts. While not much difference was observed in original FTIR spectra between these samples, spectral treatments by Fourier self-deconvolution (FSD) and peak-smoothing in the regions between 2000 and $1000 \mathrm{~cm}^{-1}$ showed that the differences in band patterns observed between transgenic cottonseeds and their counterparts depended on the varieties used.

A thermogravimetric analyzer (TG) is another advanced instrument used to analyze the mass changes of a sample with increasing temperatures and time [42]. Heat treatments such as roasting and frying are frequently employed in the food processing of seeds and nuts to improve their sensory quality, digestibility, and microbiological safety [43-45]. Thus, TG analysis has been applied to detect the mass loss of various volatile compounds as well as appropriate roasting temperatures for heat treatments $[44,46,47]$. The coupling of TG with FTIR (i.e., TG-FTIR) has provided a unique capability to obtain the transient mass loss and evaluation of the volatile functional groups of a sample, which could not be obtained by the TG and FTIR individually [42,48]. In previous research, this technology revealed the presence of phenols, esters, alcohols, and aldehydes as the volatile compounds in hazel sterculia (Sterculia foetida L.) seeds [49]. Examination of defatted safflower seeds by TGFTIR analysis found that $\mathrm{CO}_{2}, \mathrm{C}_{6} \mathrm{H}_{5} \mathrm{OH}$, and $\mathrm{C}=\mathrm{C}$-containing compounds were the main pyrolysis gas products of defatted safflower seeds [50]. TG-FTIR observations have shown that the devolatilization sensitivity to heating rate followed the order of hemicellulose $>$ starch $>$ oil $>$ cellulose $\approx$ protein $>$ lignin [51]. In a characterization of five herb essential oils, the TG of the essential oils and the TG-FTIR analyses of the evolved gases showed that the essential oils' thermal behavior was due to the volatilization of the major components in these herbs without thermal degradation [52].

Similarly, data on the thermal behavior and stability will be useful for safe and proper handling of cottonseed during product formulations. To the best of our knowledge, there are only limited TG-FTIR studies of cottonseed with the purpose of pyrolysis applications so far [53-55]. Thus, in this research work, chemical analysis, FTIR, and TG-FTIR were applied to evaluate the thermochemical properties of Gd and Gl cottonseed kernels. Knowledge and data obtained from the thermal behavior and stability are useful for a safe and proper handling of cottonseed during product formulation for food and non-food applications. Therefore, the primary objective of this research was to determine the thermal properties and stability of Gd and Gl using TG-FTIR analysis.

\section{Results and Discussion}

\subsection{Chemical Composition of $G d$ and $G l$ Kernels}

Selected chemical components of Gd and Gl cottonseed kernels are listed in Table 1. These data are generally in the range described in the literature [56-59]. The unique features in the presence or absence of gossypol are clearly demonstrated by the difference in gossypol content between the two types of cottonseeds. These data indicated that Gl kernels, but not the Gd kernels, meet FDA's criteria as human food products with free gossypol $<450 \mathrm{ppm}[2,23]$. Otherwise, the chemical components of $\mathrm{Gd}$ and $\mathrm{Gl}$ were quite similar. In both types of kernels, oil and protein accounted for about $40 \%$ of the total biomass. The carbohydrates, moisture, and mineral ash constituted the remaining biomass. Even though a significant $(p<0.05)$ difference was observed, the starch content was low in both Gd and Gl samples, consistent with the data in the literature [22,60]. While cottonseed could be a source of human food and animal feed for low-starch diets [22], external addition of starch may promote the processing and dietary properties of cottonseed products [24,26]. Statistically significant $(p \leq 0.05)$ differences were also observed in the contents of protein and total phosphorus between Gd and Gl kernels. The similar significant impact seems 
reasonable as phosphorus in cottonseeds is generally present in the phytate form [61] and positively correlated with cottonseed protein content [62]. While the composition of major components of the $\mathrm{Gd}$ and $\mathrm{Gl}$ cottonseeds are available in the literature [22,23], Table 1 also compared the mineral contents between the two types of cottonseeds. Twelve of the thirteen minerals (except for $\mathrm{Al}$ ) are essential elements. Aluminum is a non-essential element whose presence is of concern to both human and ecosystem health $[56,63]$. The general similarity of the mineral levels between the two cottonseeds implied that the decrease of gossypol in $\mathrm{Gl}$ cottonseed did not dramatically alter the mineral composition of cottonseeds. Therefore, the quality of mineral nutrients of the cottonseeds was not impacted by the reduction of the toxicity of high gossypol content.

Table 1. Selected chemical components of Gd and Gl cottonseed kernels. Data are reported on a dry weight basis with average (A) and standard deviation (SD, $n=3)$. ADF, acid detergent fiber. ADL, acid detergent lignin.

\begin{tabular}{|c|c|c|c|c|c|c|c|}
\hline \multicolumn{8}{|c|}{ (A) Major component $\left(\mathrm{g} \mathrm{kg}^{-1}\right)$} \\
\hline & Moisture & Gossypol ***1 & Oil & Protein ** & ADF & ADL & Starch ** \\
\hline $\mathrm{Gd}$ & $67.9 \pm 0.5$ & $3.75 \pm 0.02$ & $387 \pm 18$ & $397 \pm 8$ & $100 \pm 18$ & $52.3 \pm 10.1$ & $12.2 \pm 1.0$ \\
\hline Gl & $68.3 \pm 0.2$ & $0.06 \pm 0.00$ & $350 \pm 14$ & $421 \pm 6$ & $109 \pm 23$ & $67.8 \pm 15.6$ & $16.6 \pm 0.4$ \\
\hline \multicolumn{8}{|c|}{ (B) Macro element and ash $\left(\mathrm{g} \mathrm{kg}^{-1}\right)$} \\
\hline & $\mathrm{P}^{*}$ & $\mathrm{Ca}$ & K & $\mathrm{Mg}$ & $\mathrm{Na}$ & $S$ & Ash \\
\hline $\mathrm{Gd}$ & $9.8 \pm 0.8$ & $2.0 \pm 0.3$ & $12.0 \pm 0.7$ & $5.4 \pm 0.4$ & $0.6 \pm 0.0$ & $4.5 \pm 0.3$ & $46.7 \pm 0.8$ \\
\hline Gl & $11.5 \pm 0.6$ & $2.3 \pm 0.2$ & $12.8 \pm 0.5$ & $6.1 \pm 0.3$ & $0.6 \pm 0.0$ & $4.9 \pm 0.2$ & $47.9 \pm 0.7$ \\
\hline \multicolumn{8}{|c|}{ (C) Trace element $\left(\mathrm{mg} \mathrm{kg}^{-1}\right)$} \\
\hline & $\mathrm{Fe}$ & $\mathrm{Zn}$ & $\mathrm{Cu}$ & $\mathrm{Mn}$ & B & $\mathrm{Ni}$ & $\mathrm{Al}$ \\
\hline $\mathrm{Gd}$ & $104 \pm 43$ & $70.5 \pm 8.2$ & $18.1 \pm 1.1$ & $12.9 \pm 1.2$ & $13.8 \pm 1.1$ & $1.9 \pm 0.3$ & $91.6 \pm 61.2$ \\
\hline Gl & $111 \pm 3$ & $74.3 \pm 2.5$ & $19.0 \pm 1.2$ & $13.3 \pm 0.7$ & $14.2 \pm 0.5$ & $2.1 \pm 0.1$ & $109.8 \pm 8.4$ \\
\hline
\end{tabular}

${ }^{1}$ Symbols ${ }^{* * *}$, and ${ }^{* * *}$ indicate the values between $\mathrm{Gd}$ and $\mathrm{Gl}$ samples significantly differed at $p \leq 0.05,0.01$ and 0.001 , respectively.

\subsection{Microstructure of $G d$ and $G l$ Cottonseed Kernels}

Figure 2 shows the SEM images of the Gd and Gl kernel particles and their extraction residues at two different scales. The SEM images of both Gd-k and Gl-k appear to have no apparent differences. The images at the larger scale $(1 \mathrm{~mm})$ showed that the powder particles of both kernels seemed to form sticky aggregates. The images at the smaller scale $(10 \mu \mathrm{m})$ revealed that the morphology of these kernel powders had stacked granules of irregular spherical shapes. By careful comparison of the images of Gd-k2 and Gl-k2, it can be seen that the granule surfaces of the latter are smoother than the former. These micrographs indicate that the presence of gossypol did not result in any difference in micromorphology of the two types of cottonseed powders. On the other hand, some differences in the microstructures were observed in the kernel residues after hexane and $80 \%$ ethanol extraction. In a comparison to Gd-k1 and Gl-k1, the images of the Gd-r1 and Gl-r1 appeared to be more separated and with large chunks disrupting the outer layer of the fibers, similar to the microstructures of those defatted cottonseed and soy meal products $[64,65]$. Thus, we attributed this micromorphological difference to the oil component. Another observation was that almost all granules in the Gl-k2 image were round and smoothy, but there were only a few such round-shaped granules in the microstructural matrix in the Gd-r2 image (Figure 2). More data from future research are needed to confirm if the microstructural difference was due to the effects of a broken gossypol gland wall matrix which is not hexane extractable [66]. 

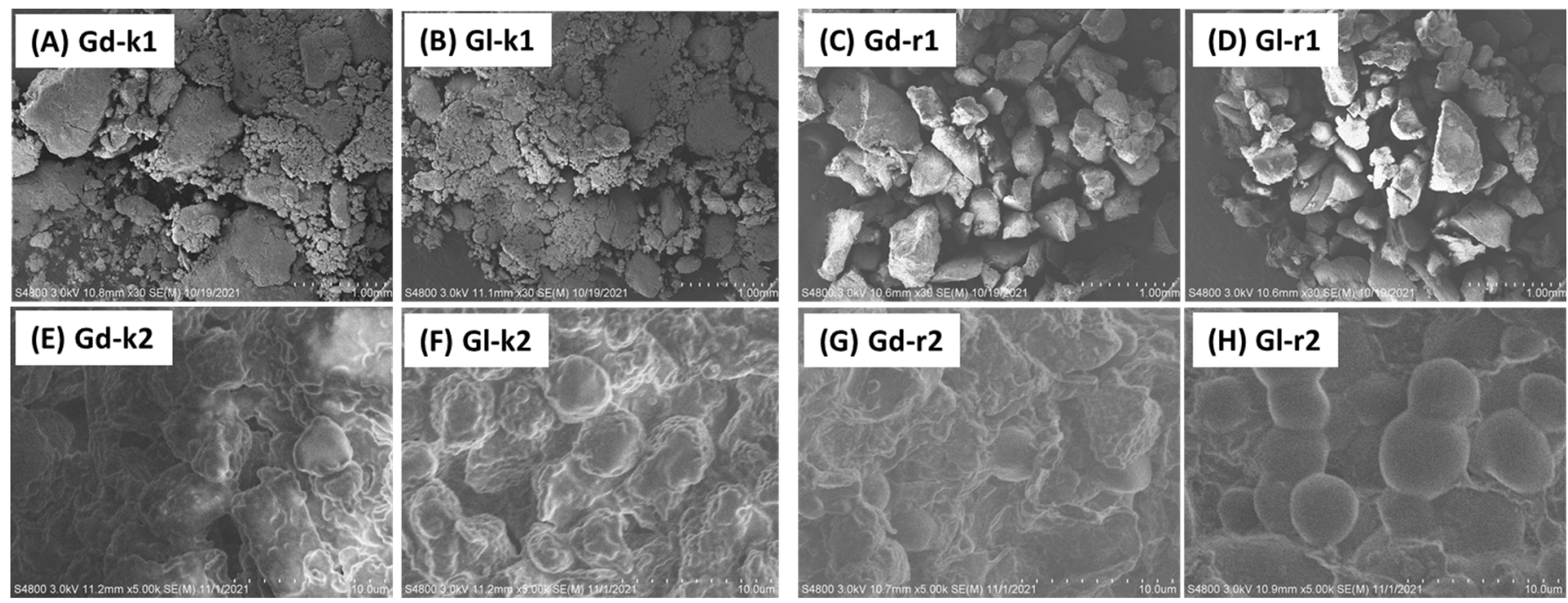

Figure 2. SEM images of Gd and Gl kernels (Gd-k and Gl-k) and their residues (Gd-r and Gl-r) after sequential 100\% hexane and 80\% ethanol (in water) extractions. Bar distances are $1.00 \mathrm{~mm}$ and $10 \mu \mathrm{m}$, respectively, for series 1 (upper row panel (A-D)) and 2 (lower row panel (E-H)) images.

\subsection{ATR FTIR Spectra of Gd and Gl Kernels and Their Extraction Residues}

The ATR FTIR spectra of the four samples are shown in Figure 3. As per the previous band assignments of cotton biomass sample research [31,32,38,44,67], the typically broad and strong band around $3288 \mathrm{~cm}^{-1}$ was due to the $\mathrm{O}-\mathrm{H}$ or $\mathrm{N}-\mathrm{H}$ stretching modes of carbohydrates, adsorbed water, and proteins. The twin or triple bands at 2927 and $2854 \mathrm{~cm}^{-1}$ were assigned to hydrophobic $\mathrm{CH}_{2}$ asymmetrical and symmetrical stretching vibrations from the oil portion in cottonseed. The band at $1745 \mathrm{~cm}^{-1}$ was contributed by the $\mathrm{C}=\mathrm{O}$ stretching modes of carbonyl groups. The bands at 1632,1539 , and $1235 \mathrm{~cm}^{-1}$ were attributed to amide I ( $\mathrm{C}=\mathrm{O}$ stretching), II ( $\mathrm{CN}$ stretching, $\mathrm{NH}$ bending), and III ( $\mathrm{CN}$ stretching, NH bending) bands of proteins, respectively. The bands at $1070-995 \mathrm{~cm}^{-1}$ were assigned mainly to carbohydrates with a possible minor contribution of phosphate in cottonseeds. Similar to the chemical composition, the spectral features of Gd and Gl samples were similar with some differences only in band strength. Therefore, gossypol did not make any remarkable visual differences in the FTIR spectral features of Gd and Gl samples. This is only due to the low gossypol content $(0.375 \%)$, and also due to the fact that the FTIR spectrum of gossypol possesses no unique spectral features, rather than the general band characteristics of aromatic rings, aldehydes, and phenolic hydroxyl groups [68]. A complicated mathematical model is needed to reveal the gossypol-related difference between $\mathrm{Gd}$ and $\mathrm{Gl}$ samples, such as a partial squares method based on all the band data from $3700-2400 \mathrm{~cm}^{-1}$ and from $1900-750 \mathrm{~cm}^{-1}$ for determination of gossypol in cottonseed oil samples [68].

After sequential 100\% hexane and 80\% ethanol extraction, the spectra of the residues (Gd-r and Gl-r) (Figure 3) of the two kernels showed relatively weaker peaks around the 2927 and $2854 \mathrm{~cm}^{-1}$ region, compared to the unextracted kernel samples (Gd-k and Gl-k), apparently due to the removal of the oil components $[32,69]$. This observation was further confirmed by the ATR FTIR spectra of the hexane extracts (Gd-n and Gl-n) (Figure 4), which are typical for seed oil samples with strong bands at 2927 and $2854 \mathrm{~cm}^{-1}$ regions as well as at $1745 \mathrm{~cm}^{-1}[32,70]$. Compared to the Gd-k and Gl-k samples, Gd-n and Gl-n showed a more apparent minor peak at $3009 \mathrm{~cm}^{-1}$. This peak was associated with the stretching vibration of $\mathrm{CH}$ cis-olefinic groups [45]. In comparison to their untreated kernel samples, no other apparent changes in FTIR features of the extraction residues (Gd-r and Gl-r) were observed, leading to their features being similar to those of defatted cottonseed meal products [71]. 


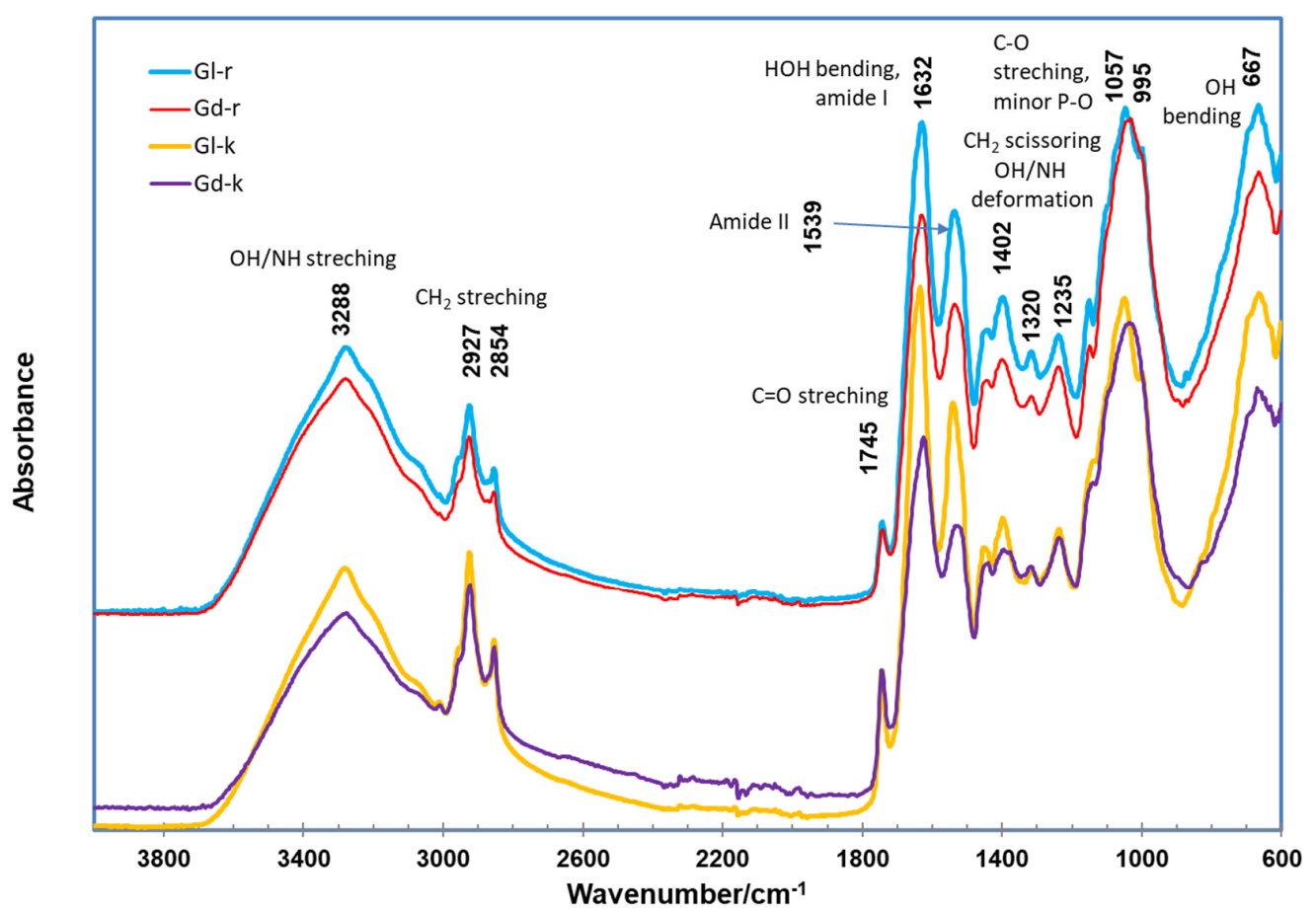

Figure 3. ATR FTIR spectra of Gd and Gl kernels (Gd-k and Gl-k) and their residues after 100\% hexane and $80 \%$ ethanol (in water) extraction (Gd-r and Gl-r).

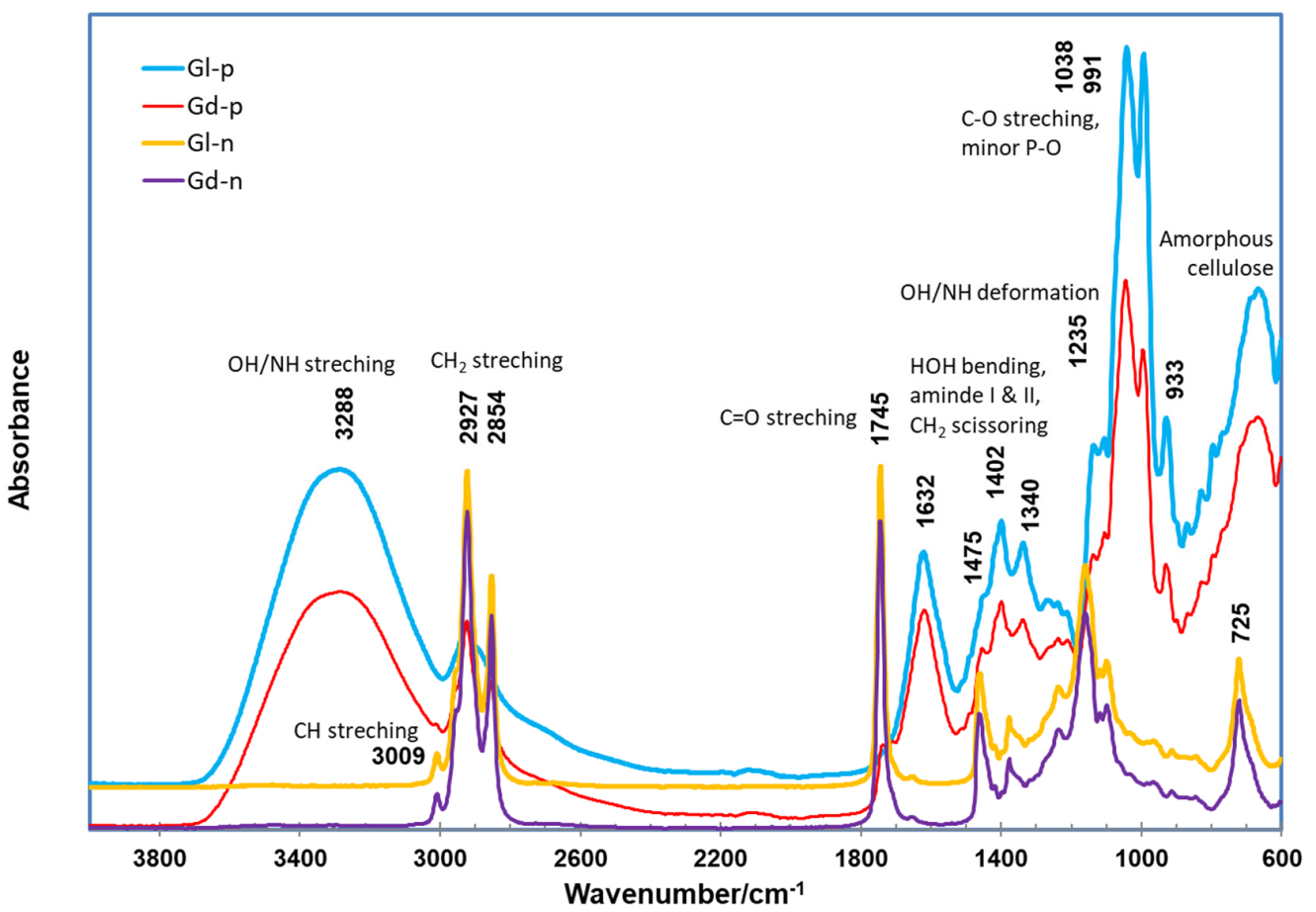

Figure 4. ATR FTIR spectra of the extracts of Gd and Gl kernels by nonpolar $100 \%$ hexane (Gd-n and Gl-n) and polar 80\% ethanol (Gd-p and Gl-p).

As there were only minor spectral differences between the two cottonseed samples, we further examined the spectral features of the hexane and methanol extracts of $\mathrm{Gd}$ and Gl samples to enhance the understanding of the chemical composition of the specific extractable nonpolar and polar ingredients in cottonseeds. The spectra of the ethanol extracts (Gd-p and Gl-p) were totally different from the features of nonpolar extracts 
Gd-n and Gl-n, and were characterized by the highest bands of carbohydrates at the $1038-991 \mathrm{~cm}^{-1}$ region (Figure 4 ). While no FTIR information on the ethanol extracts of cottonseed kernels is available in the literature, HPLC-MS analysis revealed the ethanol extracts of Gd and Gl cottonseed with 27 peaks and mass values equivalent to possible flavonols or derivatives and 16 peaks possible matched to apiosyl, rhamnosyl, and glucosylderivative mass [17]. Ultrahigh resolution mass spectrometry may be needed to identify definitely these compounds in the ethanol extracts of Gd and Gl kernels [72].

\subsection{Thermogravimetric Observations}

The TG plots of the Gd and Gl samples are shown in Figure 5, respectively. The general features of these TG and DTG plots were the typical three-stage (drying, de-volatilization, and char formation) weight loss of the testing samples over the heating temperature range from $50-700{ }^{\circ} \mathrm{C}$. Analysis of the first derivative curves of the TG measurement (DTG) of the kernel samples showed more clearly that the second stage of decomposition processed with three substeps had maximum temperature peaks of around 215 (shoulder), 315 (shoulder), and $380{ }^{\circ} \mathrm{C}$ (major peak) (Figure 5). This thermal behavior of cottonseed kernels was more complex than the relative sample DTG curves of cottonseed oil [73], protein [36], and fiber [30]. Furthermore, the DTG curves of the extraction residues (Gd-r and Glr) showed different decomposition characteristics with the unnoticeable first shoulder $\left(215^{\circ} \mathrm{C}\right)$, a major peak at $380{ }^{\circ} \mathrm{C}$, and switching the peak at $380{ }^{\circ} \mathrm{C}$ to a shoulder. Thus, in addition to the attributed common decomposition of hemicellulose, cellulose, and lignin assigned for cottonseed and other natural products $[48,53,55]$, the differences of DTG maximal temperature peak shape between the kernels (Gd-k and Gl-k) and extraction residues (Gd-r and Gl-r) indicated that the oil component should be a major contribution of the decomposition around $380^{\circ} \mathrm{C}$. Those ethanol extractable compounds volatilized or decomposed around $215^{\circ} \mathrm{C}$. Protein components were decomposed in a wide range of temperatures from 215 to $380{ }^{\circ} \mathrm{C}[36,74]$.

The thermal gravimetric observations of the Gd and Gl samples were similar, but not exactly like those of cottonseed samples in the literature [53-55]. The differences were due to the fact that dehulled kernels were used in the study while whole cottonseeds were used in the three studies reported previously. Similar to the thermal behavior of hazel seeds [49], the first stage of drying of our cottonseed kernels at $90{ }^{\circ} \mathrm{C}$ was the loss of moisture. Calculating from the weight loss from $50{ }^{\circ} \mathrm{C}$ to $144{ }^{\circ} \mathrm{C}$ as the onset of decomposition, the evaporation (drying) of moisture contents of Gd-k was about 5.9\% weight loss (Table 2). In the second stage of devolatilization, the rapid decomposition of the sample occurred between 150 and $472{ }^{\circ} \mathrm{C}$ representing about $70.4 \%$ (i.e., $80.3 \%\left(\mathrm{WL}_{\mathrm{e}}\right)-5.9 \%\left(\mathrm{WL}_{\mathrm{o}}\right)$ ) weight loss due to devolatilization, breaking of chemical bonds, and destruction of the parent molecular skeletons. In the last stage above $472{ }^{\circ} \mathrm{C}$ (degradation), decomposition of char (19.7\%) occurred with the formation of secondary pyrolytic vapors, but some char or ash remained $(<16.1 \%)$. While the Gl-k sample demonstrated similar thermogravimetric properties, the values of four of the seven parameters measured (Table 2) were significantly different $(p \leq 0.05)$ from the corresponding values of the Gd-k sample. Compared to Gd-k, Gl-k kernels started the devolatilization stage at a higher temperature $\left(147^{\circ} \mathrm{C}\right)$, but the ending temperature $\left(469^{\circ} \mathrm{C}\right)$ was lower. Despite this, there was more weight loss of Gl-k $(82.2 \%)$ than Gd-k $(80.3) \%$. In contrast, the $T_{o}$ values differed only significantly between the residual Gd-r and Gl-r samples. Therefore, the thermogravimetric properties of the two extraction residues were more similar to each other than the Gd and Gl kernels themselves. This observation implied that the extractable components in Gl kernels were less thermally stable. However, we did not establish a correlation of the thermogravimetric difference with any of these components between Gd and Gl-samples. 

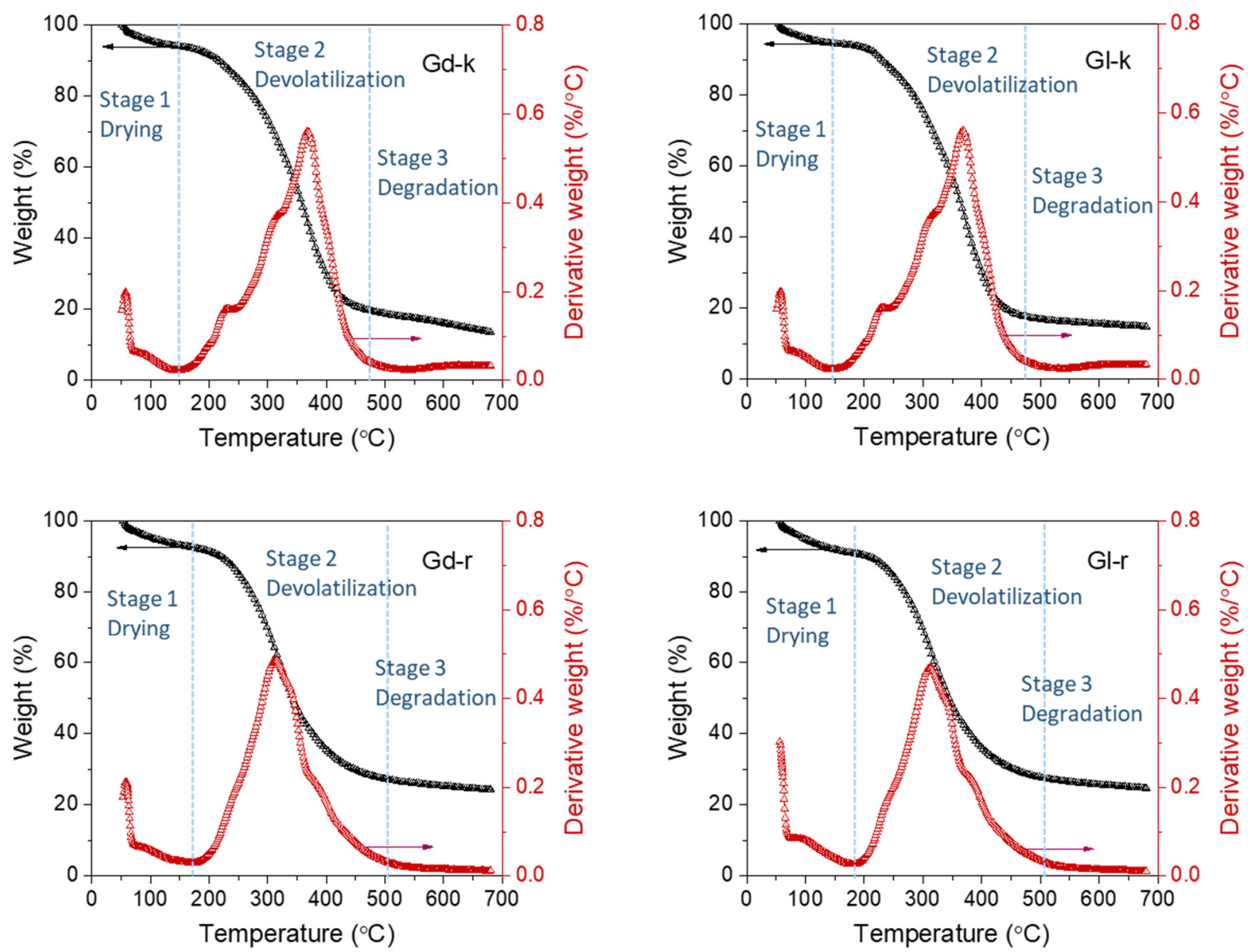

Figure 5. Thermograms of Gd and Gl kernels (Gd-k and Gl-k) and their residues after hexane and 80\% ethanol extraction (Gd-r and Gl-r). Left y axis: TG plots. Right y axis: DTG plots.

Table 2. Thermogravimetric and differential thermogravimetric data for Gd and Gl cottonseed kernels. $T$ : temperature; $W L$ : weight loss; ${ }_{0}$ : onset decomposition; $m$ : maximum decomposition rate; $e$ : end decomposition. Data are presented as the average of triplicate measurements with standard deviation in parentheses. Symbol *, and ns at the data in row Gl-k and Gl-r indicate the values of the Gl samples significantly and not significantly different $(p=0.05)$, respectively, from their corresponding Gd-k and Gd-r samples.

\begin{tabular}{cccccccc}
\hline & $\mathbf{T}_{\mathbf{o}}\left({ }^{\circ} \mathbf{C}\right)$ & $\mathbf{W L}_{\mathbf{o}}(\mathbf{\%})$ & $\mathbf{T}_{\mathbf{m}}\left({ }^{\circ} \mathbf{C}\right)$ & $\mathbf{W L}_{\mathbf{m}}(\%)$ & $\mathbf{T}_{\mathbf{e}}\left({ }^{\circ} \mathbf{C}\right)$ & $\mathbf{W L}_{\mathbf{e}}(\mathbf{\%})$ & $\left.\mathbf{C h a r}^{(\%)}\right)^{\mathbf{1}}$ \\
\hline Gd- & 143.5 & 5.9 & 368.4 & 55.9 & 471.7 & 80.3 & 16.1 \\
$\mathrm{k}$ & $(1.2)$ & $(0.7)$ & $(0.8)$ & $(0.5)$ & $(1.2)$ & $(0.7)$ & $(1.5)$ \\
\hline Gl- & $147.1^{*}$ & $5.5 \mathrm{~ns}$ & $368.4 \mathrm{~ns}$ & $52.9 *$ & $468.7 *$ & $82.2 *$ & $15.6 \mathrm{~ns}$ \\
$\mathrm{k}$ & $(1.3)$ & $(0.9)$ & $(0.7)$ & $(0.7)$ & $(1.5)$ & $(1.1)$ & $(1.1)$ \\
\hline $\mathrm{Gd}-$ & 177.9 & 7.6 & 313.2 & 36.8 & 504.9 & 72.9 & 25.3 \\
$\mathrm{r}$ & $(1.2)$ & $(1.0)$ & $(0.9)$ & $(1.1)$ & $(1.2)$ & $(1.2)$ & $(1.2)$ \\
\hline $\mathrm{Gl}-$ & $183.6^{*}$ & $9.1 \mathrm{~ns}$ & $314.5 \mathrm{~ns}$ & $37.4 \mathrm{~ns}$ & $504.9 \mathrm{~ns}$ & $72.4 \mathrm{~ns}$ & $25.7 \mathrm{~ns}$ \\
$\mathrm{r}$ & $(1.0)$ & $(0.8)$ & $(0.9)$ & $(1.0)$ & $(1.0)$ & $(0.9)$ & $(1.3)$ \\
\hline
\end{tabular}

1 , char yield measured at $600{ }^{\circ} \mathrm{C}$.

High-quality cottonseed and its derived products/byproducts have been developed as animal feeds and human foods [23,26,75-78]. These low quality or non-edible cottonseed, oil, and other byproducts may be used for raw materials of bio-fuels and biochars [54,55,79-81] These applications are frequently involved with various heat pre-treatments (such as low- 
temperature roasting/frying and mid- or high-temperature pyrolysis). While there are no clear-cut point of temperature settings for each heat treatment, thermogravic observations would be helpful in understanding the chemicophysical changes of the cottonseed under a given heating temperature range. Specifically, the temperature of the devolatilization stage would be a critical reference for product optimization (such as flavors of roasting and yield of bio-oil/bio-gas) as vaporization of the volatile components of the biomass occur. Thus, we applied TG-FTIR to elucidate more information on transient mass loss and evaporation of the volatile functional groups of the two cottonseed samples during the stage (Section 2.5).

\subsection{TG-FTIR Observations}

The three-dimensional TG-FTIR spectra with the coordinates of absorbance, wave number, and temperature of the four samples are shown in Figure 6. This methods of TG analysis coupled with IR spectroscopy detected the real-time gaseous products that evolved during the pyrolysis process [48]. The intensive FTIR signals of the evolved gases were detected within a temperature range of 150 and $500{ }^{\circ} \mathrm{C}$ which is consistent with TGA measurements (Figure 5). The presence of $\mathrm{H}_{2} \mathrm{O}$ was demonstrated by $\mathrm{O}-\mathrm{H}$ stretching vibrations between $4000-3400 \mathrm{~cm}^{-1}$ and the sharp band at $1514 \mathrm{~cm}^{-1}$ [48]. The broad band in the range of $3000-2700 \mathrm{~cm}^{-1}$ represented hydrocarbon gases, mainly $\mathrm{CH}_{4}$, and the remarkable peak and a small band between 2400 to $2000 \mathrm{~cm}^{-1}$ represented the $\mathrm{C}=\mathrm{O}$ stretching vibrations of $\mathrm{CO}_{2}$ and $\mathrm{CO}[49,53]$. The presence of aldehydes, ketones, and acids was indicated by the band at $1776 \mathrm{~cm}^{-1}$. The broad bands between $1460-1365 \mathrm{~cm}^{-1}$ and 1200-1000 $\mathrm{cm}^{-1}$ were attributed to the presence of $\mathrm{C}-\mathrm{H}$ alkanes, esters, and alcohols. In addition, the band between 1200 to $1000 \mathrm{~cm}^{-1}$ further confirmed the presence of alcohol in these gaseous products $[48,49]$.
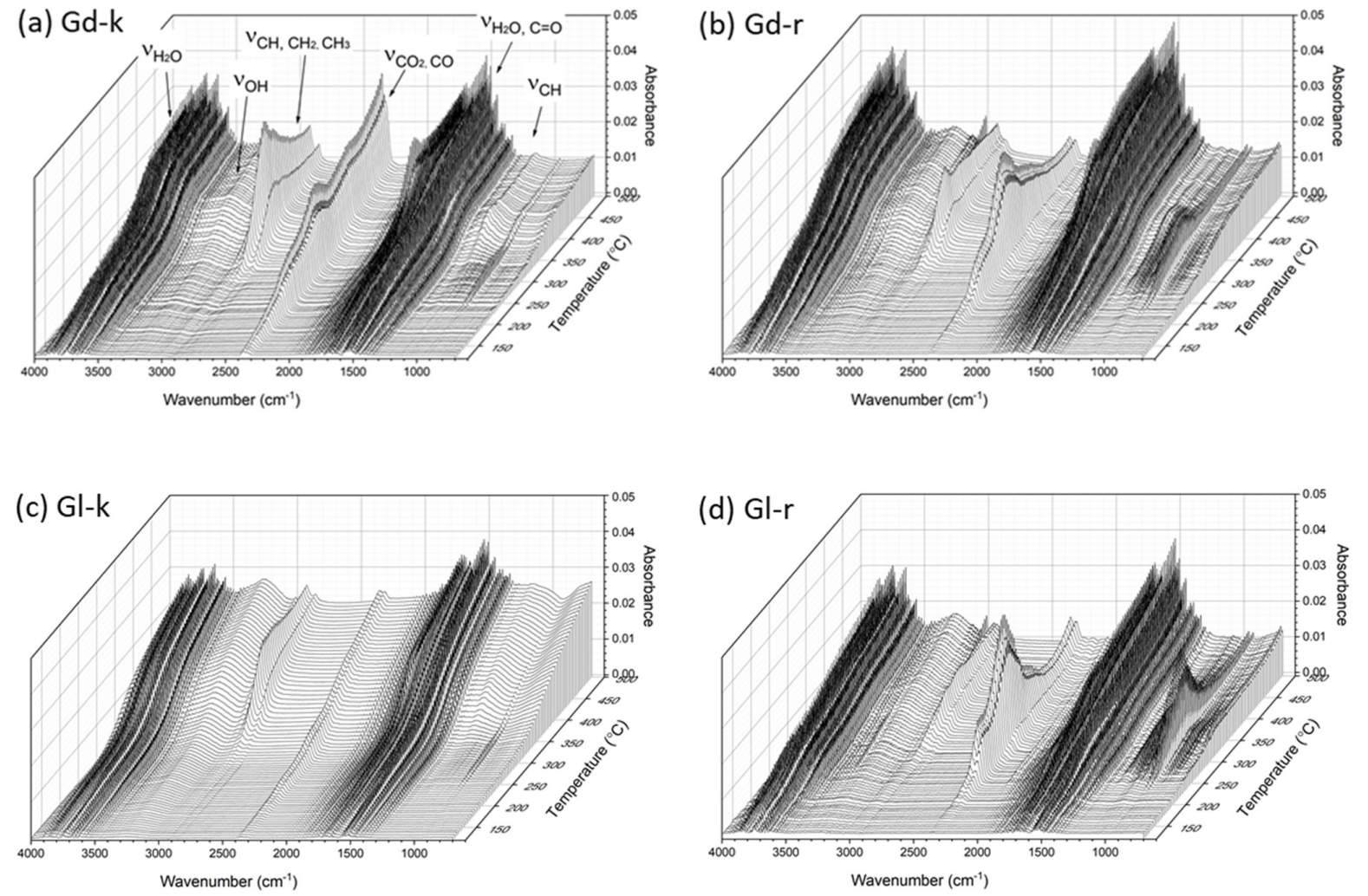

Figure 6. TG-FTIR spectra of Gd and Gl kernels (Gd-k and Gl-k) and their residues after 100\% hexane and $80 \%$ ethanol extraction (Gd-r and Gl-r).

The main differences between the TG-FTIR spectra of the Gd-k and Gl samples were the presence of much stronger peaks in three regions of $3000-2700 \mathrm{~cm}^{-1}\left(\mathrm{CH}_{4}\right), 2400-2300 \mathrm{~cm}^{-1}$ 
$\left(\mathrm{CO}_{2}, \mathrm{CO}\right)$ and the minor bands around $1000 \mathrm{~cm}^{-1}$ (alcohol) with the Gd-k sample. This observation implied that the biomass components in Gd kernels decomposed faster than those in Gl kernels. However, the spectra of the residues after hexane and ethanol extractions of the glanded and glandless cottonseed samples were more similar to each other. Indeed, the FTIR bands in the three above regions were somewhat stronger in Gl-r sample than Gd-r samples. As the two-step extractions mainly removed the major oil components and minor flavonols or similar compounds alike [17], it seemed that the oil component made the difference in TG-FTIR spectra of Gd and Gl samples. As free gossypol is lipophilic [68], we hypothesize that it was gossypol dissolved in oil that promoted the faster devolatilization in the glanded cottonseed kernel sample GD-k although the hypothesis should be further examined with more experimental data. The TG-FTIR spectra also showed that the $\mathrm{CO}_{2}$ and CO bands (2400-2300 $\left.\mathrm{cm}^{-1}\right)$ reached the highest point around $315^{\circ} \mathrm{C}$, but the $\mathrm{CH}_{4}$ peak $\left(3000-2700 \mathrm{~cm}^{-1}\right)$ was at its highest point later at approximately $375{ }^{\circ} \mathrm{C}$. The latter $\mathrm{CH}_{4}$ peak was also weaker in the oil-extracted residual samples (Gd-r and Gl-r) than their corresponding original kernel samples (GD-k and Gl-k), indicating that $\mathrm{CH}_{4}$ detected in the TG-FTIR spectra was mainly from the oil component of cottonseed. In contrast to that, these $\mathrm{CO}_{2}$ and $\mathrm{CO}$ products that appeared at early stages should be mainly from carbohydrates (cellulose, hemicellulose, starch) [48,51]. Compared to the kernel samples, the relatively stronger multiple bands from 1500 to $700 \mathrm{~cm}^{-1}$ in Gd-r and Gl-r) indicated easier decomposition of protein components after oil removal [51]. This observation was supported by N-enriched compounds of the defatted cottonseed meal bio-oil which were the condensed gaseous products of pyrolysis $[54,80]$. In other words, it was difficult to pyrolyze the biomass rich in oil and lignin but easy to pyrolyze the biomass rich in cellulose, starch, hemicellulose, and protein [51].

Similar to other seeds or nuts for food applications [45,47,82-85], roasting is a necessary heating process for enhanced use of cottonseed kernels as nutrient food products [23]. While roasting temperatures were reported in the range of 100 to $160{ }^{\circ} \mathrm{C}$ for various plant-based butters [86], the negligible $\mathrm{CO}_{2}$ and $\mathrm{CO}$ bands $\left(2400-2300 \mathrm{~cm}^{-1}\right)$ in TG-FTIR spectra of Gd-k and Gl-k below $215^{\circ} \mathrm{C}$ of the first shoulder in DTG curves (Figure 5) suggested that the cottonseed kernels could be roasted in the temperature range without significant occurrence of decomposition (carbonization). On the other hand, the optimal roasting temperature would be lower than or around $140-150{ }^{\circ} \mathrm{C}$ in the first stage of drying or dehydration (Figure 5) to reduce evaporation of some volatile flavor compounds [43]. The TG-FTIR spectra also confirmed that 350 to $500^{\circ} \mathrm{C}$ were optimal pyrolysis temperatures of cottonseed kernels and their defatted residues (i. e., defatted meal or cake) for bio-oil and biochar production $[55,80,87]$ with some flexibility of higher temperatures (e.g., $\left.600-700{ }^{\circ} \mathrm{C}\right)[53,54]$.

\section{Materials and Methods}

\subsection{Cottonseed Source and Treatment}

The Gl cottonseed of the NuMex series was provided by Cotton, Inc. (Cary, NC, USA) $[9,88]$. These seeds were dehulled mechanically by cracking with a $20.32 \mathrm{~cm}$ plate mill, and then separated with a vibration shaker. The kernel products were further cleaned by passing the material through a laboratory aspirator to remove the non-kernel material. The presence of contamination of Gd cottonseeds in the Gl products due to cross fertilization by windblown or insect-carried pollen of Gd varieties was noticeable [23]. These Gd kernels were hand-picked or removed and used as the comparative Gd sample in this study. Both $\mathrm{Gl}$ and $\mathrm{Gd}$ kernels were then ground for $3 \mathrm{~min}$ in a stainless-steel jar of Waring Commercial Blender (Model WF2211214, Torrington, CT, USA). The experimental procedure, methodologies, and sample labelling are shown in Figure 7 and described in the sub-sections below. 


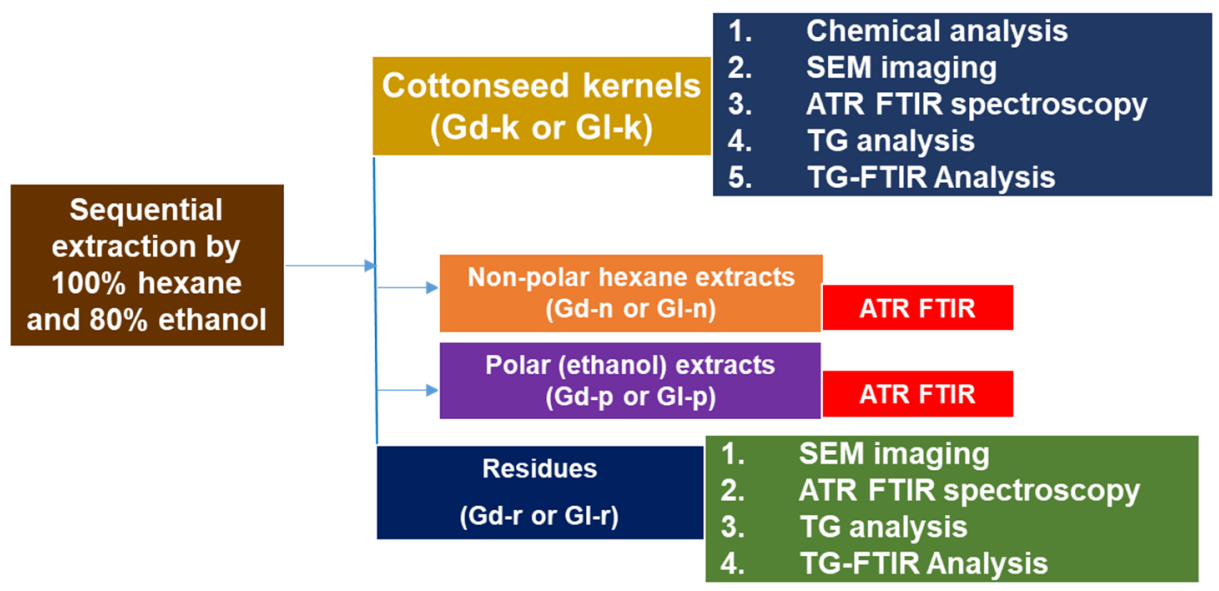

Figure 7. Flow chart of the sample processing, experimentation, and analysis performed in this work. Gd series, glanded cottonseed samples; Gl series, glandless cottonseed samples.

\subsection{Non-Polar and Polar Solvent Extraction}

Cottonseed kernels were subjected to sequential extraction by $100 \%$ reagent grade hexane $[89,90]$ and $80 \%$ reagent grade ethanol in water $[17,83]$. Grounded Gd and Gl kernels $(5.00 \mathrm{~g}$ each) were placed in $50 \mathrm{~mL}$ centrifuge tubes with $15 \mathrm{~mL}$ of hexane and extracted overnight $(18 \mathrm{~h})$ at room temperature $\left(26^{\circ} \mathrm{C}\right)$ under rotary shaking $(60 \mathrm{rpm})$. Those tubes were then centrifuged for $30 \mathrm{~min}$ at $5{ }^{\circ} \mathrm{C}$ and $2500 \times \mathrm{g}$. After centrifugation, the supernatant in each tube was carefully removed and the pellets (residual parts) were extracted one more time following the same procedure mentioned above. The residual parts were subsequently washed twice with hexane $(5 \mathrm{~mL}$ each). The supernatants and washing solutions of each tube were pooled and placed in a venting hood to evaporate hexane out at room temperature. The non-evaporated part was the nonpolar oil fraction of the cottonseed kernels. The dried residual pellets were further extracted twice by $80 \%$ ethanol $(15 \mathrm{~mL}$ each) following the same procedure as in the hexane extraction. Both the ethanol supernatants (polar extracts) and the extracted residues were dried in a vacuum oven at $40{ }^{\circ} \mathrm{C}$ to constant weights.

\subsection{Microstructural Imaging Analysis}

For scanning electron microscopy (SEM), a thin layer of sample particles (grounded cottonseed kernel or the extraction residues) was gently attached to an $8 \mathrm{~mm} \times 12 \mathrm{~mm}$ double-side sticky carbon tape on an aluminum stud. The butter sample was coated with $3 \mathrm{~nm}$ thickness of carbon using a Cressington 208HR Sputter Coater (Watford, England, UK). The cottonseed kernel samples were observed and imaged with a Hitachi S-4800 Field Emission Scanning Electron Microscope (Hitachi, Japan), operating at 3 kV [30]. Microscopic images were done on multiple samples with different scales and the representative images were reported.

\subsection{Chemical Analysis}

All chemical analysis and data were reported on a dry weight basis. Moisture content was determined as the loss in weight upon drying a sample in a forced draft oven at $105{ }^{\circ} \mathrm{C}$ for $5 \mathrm{~h}$ [91]. Both (+) and (-)isomers of gossypol were detected by a modified procedure of AOCS Recommended Practice Ba 8a-99, using about $100 \mathrm{mg}$ sample for each analysis [92,93]. Briefly, $100 \mathrm{mg}$ of ground sample was weighed into a $12 \mathrm{~mL}$ screw-cap test tube. A complexing reagent $(2 \mathrm{~mL})$ consisting of 2/10/88 (v/v/v) R-(-)-2-amino-1-propanol, glacial acetic acid, and dimethylforamide was added. The tube was then heated at 95 to $100{ }^{\circ} \mathrm{C}$ for $30 \mathrm{~min}$ to convert gossypol's aldehyde groups into Schiff's bases with the chiral amine. The formed gossypol complexes were detected on-line at $254 \mathrm{~nm}$ after they were separated on a Hewlett-Packard Series 1100 HPLC system equipped with a photodiode array detector (Palo Alto, CA, USA). Total gossypol content was computed as the sum of 
these isomers. Starch content was measured per Sigma-Aldrich starch assay kit (SA20, Sigma-Aldrich, St. Louis, MO, USA). Crude protein content in the samples was calculated by multiplying the total $\mathrm{N}$ by a factor of 6.25 [57]. Oil content was estimated per the yield of hexane extraction [90]. Acid detergent fiber (ADF) and acid detergent lignin (ADL) were determined using the filter bag methods with an Ankom Fiber Analyzer (Ankom Technology, Macedon, NY, USA). The kernel samples were first pre-extracted by acetone before the fiber analysis to remove the inherent oil [94].

The elemental composition of the samples was analyzed following acid digestion. Briefly, $0.50 \mathrm{~g}$ of grounded sample was mixed in $10.0 \mathrm{~mL}$ of concentrated $\mathrm{HNO}_{3}$ for $1 \mathrm{~h}$ in a HotBlock ${ }^{\mathrm{TM}} 200$ digestion system (Environmental Express, Charleston, SC, USA). The sample was then heated to $115^{\circ} \mathrm{C}$ for $2.25 \mathrm{~h}$. The concentrations of 13 elements (i.e., $\mathrm{Al}$, $\mathrm{B}, \mathrm{Ca}, \mathrm{Cu}, \mathrm{Fe}, \mathrm{K}, \mathrm{Mg}, \mathrm{Mn}, \mathrm{Na}, \mathrm{Ni}, \mathrm{P}, \mathrm{S}$, and $\mathrm{Zn}$ ) in these digests were determined by a Spectro CirOs ICP spectrometer (Mahwah, NJ, USA) [57]. The concentrations of total N in each sample were determined using a LECO Truspec dry combustion Carbon/Nitrogen Analyzer (LECO, St. Joseph, MI, USA). Ash content was determined by measuring the residual mass of a sample $(1.0 \mathrm{~g})$ after heating in a muffle furnace at $550{ }^{\circ} \mathrm{C}$ for $4 \mathrm{~h}$ [95]. Samples were replicated $(3 \times)$ and chemical analyses were repeated.

\subsection{Instrumental Analysis}

ATR FTIR spectra were measured using a Vertex 70v FTIR spectrometer (Bruker Daltonics, Billerica, MA, USA) equipped with a MIRacle ATR accessory (Pike Technologies, Fitchburg, WI, USA) that incorporated a diamond crystal plate as the reflector. The ground solid samples or oily-like extracts were placed on the ATR crystal surface and secured with a metal clamp to ensure a reproducible pressure which was applied to the samples to achieve intimate contact with the ATR crystal. The spectra were collected over the range of $4000-600 \mathrm{~cm}^{-1}$ at $4 \mathrm{~cm}^{-1}$ resolution and with 16 scans. All spectra were normalized and presented in absorbance [80].

Thermogravimetric analysis was carried out using a TGA Q500 thermal gravimetric analyzer (TA Instruments, New Castle, DE, USA) under a nitrogen atmosphere. The nitrogen flow into the furnace was maintained at a rate of $90 \mathrm{~mL} / \mathrm{min}$. About $8 \mathrm{mg}$ of the sample placed in a platinum pan was heated to $700^{\circ} \mathrm{C}$ with a heating rate of $10^{\circ} \mathrm{C} / \mathrm{min}$. The evolved gas during the thermal decomposition of the sample was analyzed using TG-FTIR. A TG analyzer was equipped with a gas purge through which pyrolysis vapors were conveyed to a TG-FTIR interface inside the infrared spectrometer. A series of FTIR spectra were collected from $100{ }^{\circ} \mathrm{C}$ to $500{ }^{\circ} \mathrm{C}$ with 16 scans at a $4 \mathrm{~cm}^{-1}$ resolution from replicated samples. Two spectra were obtained every minute [48].

\subsection{Statistical Analysis}

Data are presented in the format of average \pm standard deviations. Average values, if significantly different $(p \leq 0.05)$, are indicated by the relevant symbols in Tables 1 and 2 .

\section{Conclusions}

This work showed a comparative investigation of the chemical and thermal properties of glanded and glandless cottonseed kernels. While the whole glanded kernels were full of visible dark gossypol gland dots, scanning electron microcopy was not able to show the microstructural difference between grounded Gd and Gl kernel particles. With only 1.6\% of the typical gossypol content of glanded kernels, the tested glandless kernels had slightly, yet statistically significant higher $(p \leq 0.05)$ contents of protein, starch and phosphorus as compared to the glanded sample. Chemical analysis and FTIR spectroscopy showed similar composition in $\mathrm{C}$ functional groups and minerals in the two types of cottonseeds. TG analysis showed a typical three-stage process (drying, de-volatilization, and char formation) of weight loss of the tested kernel samples when subjected to temperatures of $50-700^{\circ} \mathrm{C}$. TG-FTIR spectroscopy revealed apparent differences in thermogravimetric properties between the two kernel samples, as well as between the raw and extracted 
kernel samples as some components in glanded kernels were more prone to thermal decomposition than glandless kernels.

With very low gossypol content, Gl cottonseed and its derived products could be developed as value added animal feeds and human foods, and part of the low quality (or non-edible grade) Gl cottonseed as well as the high-gossypol Gd cottonseed products can be used as feedstock for bio-energy and biochars. These applications all need certain heat treatments (such as low-temperature roasting/frying, and mid- or high-temperature pyrolysis). While there is no clear cut point of temperature settings for heat processing, thermogravic observations would be helpful in understanding the chemicophysical changes of the cottonseed under a given heating temperature range. Such increased knowledge derived from this work would help in optimizing the heating processes (e.g., roasting and frying) of cottonseed kernels for enhanced food applications and pyrolysis strategies of unconsumable cottonseed or defatted meals for bio-oil and biochar production.

Author Contributions: Project conceptualization, Z.H.; methodology and investigation, Z.H., S.N., H.Z. and O.M.O.; writing—original draft preparation, Z.H.; writing—review and editing, Z.H., S.N., H.Z. and O.M.O. All authors have read and agreed to the published version of the manuscript.

Funding: This research received no external funding.

Institutional Review Board Statement: Not applicable.

Informed Consent Statement: Not applicable.

Data Availability Statement: The data presented in this study are available upon request from the corresponding author.

Acknowledgments: The authors thank Mike Dowd (USDA-ARS SRRC) and Jibao He (Tulane University) for their help on gossypol and SEM data collection. This research was supported in part by the U.S. Department of Agriculture, Agricultural Research Service. Mention of trade names or commercial products is solely for the purpose of providing specific information and does not imply recommendation or endorsement by USDA. USDA is an equal opportunity provider and employer.

Conflicts of Interest: The authors declare no conflict of interest.

Sample Availability: Samples of the cottonseed kernels with limited quantity are available from the authors.

\section{References}

1. Rojo-Gutiérrez, E.; Buenrostro-Figueroa, J.; López-Martínez, L.; Sepúlveda, D.; Baeza-Jiménez, R. Biotechnological potential of cottonseed, a by-product of cotton production. In Valorisation of Agro-Industrial Residues-Volume II: Non-Biological Approaches, Zainul Akmar Zakaria; Aguilar, C.N., Kusumaningtyas, R.D., Binod, P., Eds.; Springer: Amsterdam, The Netherlands, 2020; pp. 63-82.

2. Kumar, M.; Tomar, M.; Punia, S.; Grasso, S.; Arrutia, F.; Choudhary, J.; Singh, S.; Verma, P.; Mahapatra, A.; Patil, S. Cottonseed: A sustainable contributor to global protein requirements. Trends Food Sci. Technol. 2021, 111, 100-113. [CrossRef]

3. Statista. Global Cottonseed Production from 2013/2014 to 2020/2021. Available online: Https:/ /www.Statista.Com/statistics / 25 9489/worldwide-production-of-cottonseed/ (accessed on 1 January 2022).

4. NCPA. National Cottonseed Products Association-The Products. Available online: Https://www.Cottonseed.Com/products / (accessed on 1 January 2022).

5. He, Z.; Cheng, H.N. Preparation and utilization of water washed cottonseed meal as wood adhesives. In Bio-Based Wood Adhesives: Preparation, Characterization, and Testing; He, Z., Ed.; CRC Press: Boca Raton, FL, USA, 2017; pp. 156-178.

6. Dowd, M.K. Seed. In Cotton: Agronomy Monograph, 2nd ed.; Fang, D.D., Percy, R.G., Eds.; ASA, CSSA, and SSSA: Madison, WI, USA, 2015; Volume 57, pp. 745-781.

7. Risco, C.; Chase, C. Gossypol. In Handbook of Plant and Fungal Toxicants; D'Mello, J.P.F., Ed.; CRC Press: Boca Raton, FL, USA, 1997; pp. 87-98.

8. He, Z.; Waldrip, H.M.; Wang, Y. Application of capillary electrophoresis in agricultural and soil chemistry research. In Capillary Electrophoresis: Fundamentals, Techniques and Applications; He, Z., Ed.; Nova Science Publishers: New York, NY, USA, 2012; pp. 131-151.

9. He, Z.; Mattison, C.P.; Zhang, D.; Grimm, C.C. Vicilin and legumin storage proteins are abundant in water and alkali soluble protein fractions of glandless cottonseed. Sci. Rep. 2021, 11, 9209. [CrossRef] 
10. Xie, S.; Zhou, Q.; Zhang, X.; Zhu, T.; Guo, C.; Yang, Z.; Luo, J.; Yuan, Y.; Hu, X.; Jiao, L. Effect of dietary replacement of fish meal with low-gossypol cottonseed protein concentrate on growth performance and expressions of genes related to protein metabolism for swimming crab (Portunus trituberculatus). Aquaculture 2022, 549, 737820. [CrossRef]

11. Zhao, T.; Li, C.; Li, C.; Zhang, F.; Mei, L.; Chindudzi, E.; Chen, J.; Zhu, S. Genome-wide analysis of genetic variations between dominant and recessive nils of glanded and glandless cottons. Sci. Rep. 2019, 9, 9226. [CrossRef] [PubMed]

12. Rathore, K.S.; Pandeya, D.; Campbell, L.M.; Wedegaertner, T.C.; Puckhaber, L.; Stipanovic, R.D.; Thenell, J.S.; Hague, S.; Hake, K. Ultra-low gossypol cottonseed: Selective gene silencing opens up a vast resource of plant-based protein to improve human nutrition. Critic. Revi. Plant Sci. 2020, 39, 1-29. [CrossRef]

13. Bellaloui, N.; Saha, S.; Tonos, J.; Scheffler, J.; Jenkins, J.; McCarty, J.; Stelly, D.M. Effect of chromosome substitution from alien tetraploid cotton species in upland cotton on (+) and (-) gossypol enantiomer levels in cottonseed. J. Cotton Sci. 2021, 25, 7-20.

14. Cheng, H.N.; He, Z.; Ford, C.; Wyckoff, W.; Wu, Q. A review of cottonseed protein chemistry and non-food applications. Sustain. Chem. 2020, 1, 256-274. [CrossRef]

15. He, Z.; Zhang, D.; Cheng, H.N. Modeling and thermodynamic analysis of the water sorption isotherms of cottonseed products Foundations 2021, 1, 32-44. [CrossRef]

16. He, Z.; Cheng, H.N.; Chapital, D.C.; Dowd, M.K. Sequential fractionation of cottonseed meal to improve its wood adhesive properties. J. Am. Oil Chem. Soc. 2014, 91, 151-158. [CrossRef]

17. Cao, H.; Sethumadhavan, K.; Bland, J.M. Isolation of cottonseed extracts that affect human cancer cell growth. Sci. Rep. 2018, 8, 1-12. [CrossRef] [PubMed]

18. Cao, H.; Sethumadhavan, K.; Wu, X.; Zeng, X. Cottonseed-derived gossypol and ethanol extracts differentially regulate cell viability and vegf gene expression in mouse macrophages. Sci. Rep. 2021, 11, 15700. [CrossRef] [PubMed]

19. He, Z.; Zhang, D.; Olanya, O.M. Antioxidant activities of the water-soluble fractions of glandless and glanded cottonseed protein. Food Chem. 2020, 325, 126907. [CrossRef] [PubMed]

20. He, Z.; Zhang, D.; Cao, H. Protein profiling of water and alkali soluble cottonseed protein isolates. Sci. Rep. 2018, 8, 9306. [CrossRef] [PubMed]

21. Delgado, E.; Valverde-Quiroz, L.; Lopez, D.; Cooke, P.; Valles-Rosales, D.; Flores, N. Characterization of soluble glandless cottonseed meal proteins based on electrophoresis, functional properties, and microscopic structure. J. Food Sci. 2019, 84, 2820-2830. [CrossRef] [PubMed]

22. Spadaro, J.J.; Gardner, H.K. Food uses for cottonseed protein. J. Am. Oil Chem. Soc. 1979, 56, 422-424. [CrossRef]

23. Lusas, E.; Jividen, G. Glandless cottonseed: A review of the first 25 years of processing and utilization research. J. Am. Oil Chem. Soc. 1987, 64, 839-854. [CrossRef]

24. Reyes-Jáquez, D.; Casillas, F.; Flores, N.; Andrade-González, I.; Solís-Soto, A.; Medrano-Roldán, H.; Carrete, F.; Delgado, E. The effect of glandless cottonseed meal content and process parameters on the functional properties of snacks during extrusion cooking. Food Nutrit. Sci. 2012, 3, 1716-1725. [CrossRef]

25. Reyes-Jáquez, D.; Casillas, F.; Flores, N.; Cooke, P.; Licon, E.D.; Soto, A.S.; González, I.A.; Carreón, F.O.C.; Roldán, H.M. Effect of glandless cottonseed meal content on the microstructure of extruded corn-based snacks. Adv. Food Sci. 2014, 36, 125-130.

26. Delgado, E.; Valles-Rosales, D.; Pámanes-Carrasco, G.; Cooke, P.; Flores, N. Structural, rheological and calorimetric properties of an extruded shrimp feed using glandless cottonseed meal as a protein source. J. Aquac. Res. Develop. 2021, 12, 637.

27. Delgado, E.; Valles-Rosales, D.J.; Flores, N.C.; Reyes-Jáquez, D. Evaluation of fish oil content and cottonseed meal with ultralow gossypol content on the functional properties of an extruded shrimp feed. Aquac. Rep. 2021, 19, 100588. [CrossRef]

28. Alam, M.S.; Watanabe, W.O.; Carroll, P.M.; Gabel, J.E.; Corum, M.A.; Seaton, P.; Wedegaertner, T.C.; Rathore, K.S.; Dowd, M.K. Evaluation of genetically-improved (glandless) and genetically-modified low-gossypol cottonseed meal as alternative protein sources in the diet of juvenile southern flounder paralichthys lethostigma reared in a recirculating aquaculture system. Aquaculture 2018, 489, 36-45. [CrossRef]

29. Abidi, N.; Manike, M. X-ray diffraction and ftir investigations of cellulose deposition during cotton fiber development. Text. Res. J. 2018, 88, 719-730. [CrossRef]

30. He, Z.; Nam, S.; Fang, D.D.; Cheng, H.N.; He, J. Surface and thermal characterization of cotton fibers of phenotypes differing in fiber length. Polymers 2021, 13, 994. [CrossRef]

31. Liu, Y.; He, Z.; Shankle, M.; Tewolde, H. Compositional features of cotton plant biomass fractions characterized by attenuated total reflection fourier transform infrared spectroscopy. Ind. Crop. Prod. 2016, 79, 283-286. [CrossRef]

32. He, Z.; Liu, Y. Fourier transform infrared spectroscopic analysis in applied cotton fiber and cottonseed research: A review. J. Cotton Sci. 2021, 25, 167-183.

33. Kaur, A.; Singh, B.; Kaur, A.; Singh, N. Chemical, thermal, rheological and ftir studies of vegetable oils and their effect on eggless muffin characteristics. J. Food Process. Preser. 2019, 43, e13978. [CrossRef]

34. Mahesar, S.A.; Shah, S.N.; Mahesar, A.W.; Kandhro, A.A.; Khaskheli, A.R.; Menghwar, P.; Sherazi, S.T.H. A chemometric approach for the quantification of free fatty acids in cottonseed oil by fourier transform infrared spectroscopy. Inter. J. Food Propert. 2017, 20, 1913-1920. [CrossRef]

35. Cheng, H.N.; Kilgore, K.; Ford, C.; Fortier, C.; Dowd, M.K.; He, Z. Cottonseed protein-based wood adhesive reinforced with nanocellulose. J. Adhes. Sci. Technol. 2019, 33, 1357-1368. [CrossRef] 
36. Liu, M.; Wang, Y.; Wu, Y.; He, Z.; Wan, H. "Greener" adhesives composed of urea-formaldehyde resin and cottonseed meal for wood-based composites. J. Clean. Prod. 2018, 187, 361-371. [CrossRef]

37. Liu, Y.; He, Z.; Uchimiya, M. Comparison of biochar formation from various agricultural by-products using ftir spectroscopy. Modern Appl. Sci. 2015, 9, 246-253. [CrossRef]

38. He, Z.; Cao, H.; Cheng, H.N.; Zou, H.; Hunt, J.F. Effects of vigorous blending on yield and quality of protein isolates extracted from cottonseed and soy flours. Mod. Appl. Sci. 2013, 7, 79-88. [CrossRef]

39. Li, N.; Prodyawong, S.; He, Z.; Sun, X.S.; Wang, D. Effect of drying methods on the physicochemical properties and adhesion performance of water-washed cottonseed meal. Ind. Crop. Prod. 2017, 109, 281-287. [CrossRef]

40. Silwal, D.K.; Phambu, N.; Pokharel, B.; Aziz, A.N. Identification of hydrated and dehydrated lipids and protein secondary structures in seeds of cotton (Gossypium hirsutum) line. Pure App. Biol. 2017, 6, 965-975.

41. Sun, C.; Wu, X.; Wang, L.; Wang, Y.; Zhang, Y.; Chen, L.; Wu, Z. Comparison of chemical composition of different transgenic insect-resistant cotton seeds using fourier transform infrared spectroscopy (ftir). Afric. J. Agric. Res. 2012, 7, $2918-2925$.

42. Ong, H.C.; Chen, W.-H.; Singh, Y.; Gan, Y.Y.; Chen, C.-Y.; Show, P.L. A state-of-the-art review on thermochemical conversion of biomass for biofuel production: A tg-ftir approach. Energy Conver. Manag. 2020, 209, 112634. [CrossRef]

43. Fischer, M.; Wohlfahrt, S.; Varga, J.; Matuschek, G.; Saraji-Bozorgzad, M.R.; Walte, A.; Denner, T.; Zimmermann, R. Evolution of volatile flavor compounds during roasting of nut seeds by thermogravimetry coupled to fast-cycling optical heating gas chromatography-mass spectrometry with electron and photoionization. Food Anal. Met. 2017, 10, 49-62. [CrossRef]

44. Valdés García, A.; Beltrán, A.; Karabagias, I.; Badeka, A.; Kontominas, M.G.; Garrigós, M.C. Monitoring the oxidative stability and volatiles in blanched, roasted and fried almonds under normal and accelerated storage conditions by dsc, thermogravimetric analysis and atr-ftir. Eur. J. Lipid Sci. Technol. 2015, 117, 1199-1213. [CrossRef]

45. Valdés García, A.; Beltrán Sanahuja, A.; Karabagias, I.K.; Badeka, A.; Kontominas, M.G.; Garrigós, M.C. Effect of frying and roasting processes on the oxidative stability of sunflower seeds (Helianthus annuus) under normal and accelerated storage conditions. Foods 2021, 10, 944. [CrossRef] [PubMed]

46. Raza, H.; Zaaboul, F.; Shoaib, M.; Ashraf, W.; Hussain, A.; Zhang, L. Physicochemical and structural characterization of microwave-roasted chickpea. J. Glob. Inno. Agri. Soci. Sci 2019, 7, 23-28. [CrossRef]

47. Rojas, S.M.; Chejne, F.; Ciro, H.; Montoya, J. Roasting impact on the chemical and physical structure of criollo cocoa variety (Theobroma cacao L.). J. Food Proc. Engineer. 2020, 43, e13400. [CrossRef]

48. Nam, S.; Condon, B.D.; Liu, Y.; He, Q. Natural resistance of raw cotton fiber to heat evidenced by the suppressed depolymerization of cellulose. Polymer Degrad. Stabili. 2017, 138, 133-141. [CrossRef]

49. Volli, V.; Gollakota, A.R.K.; Shu, C.-M. Thermal behavior of hazel sterculia seeds: A tg-ftir study. J. Innov. Technol. 2021, 3, 1-6.

50. Tahir, M.H.; Mahmood, M.A.; Çakman, G.; Ceylan, S. Pyrolysis of oil extracted safflower seeds: Product evaluation, kinetic and thermodynamic studies. Bioresour. Technol. 2020, 314, 123699. [CrossRef]

51. Zong, P.; Jiang, Y.; Tian, Y.; Li, J.; Yuan, M.; Ji, Y.; Chen, M.; Li, D.; Qiao, Y. Pyrolysis behavior and product distributions of biomass six group components: Starch, cellulose, hemicellulose, lignin, protein and oil. Energy Conver. Manag. 2020, 216, 112777. [CrossRef]

52. González-Rivera, J.; Duce, C.; Falconieri, D.; Ferrari, C.; Ghezzi, L.; Piras, A.; Tine, M.R. Coaxial microwave assisted hydrodistillation of essential oils from five different herbs (lavender, rosemary, sage, fennel seeds and clove buds): Chemical composition and thermal analysis. Innov. Food Sci. Emerg. Technol. 2016, 33, 308-318. [CrossRef]

53. Apaydin-Varol, E.; Uzun, B.B.; Onal, E.; Putun, A.E. Synthetic fuel production from cottonseed: Fast pyrolysis and a tga/ft-ir/ms study. J. Anal. Appl. Pyrol. 2014, 105, 83-90. [CrossRef]

54. Seal, S.; Panda, A.K.; Kumar, S.; Singh, R. Production and characterization of bio oil from cotton seed. Environ. Progress Sustain. Energy 2015, 34, 542-547. [CrossRef]

55. Primaz, C.T.; Ribes-Greus, A.; Jacques, R.A. Valorization of cotton residues for production of bio-oil and engineered biochar. Energy 2021, 235, 121363. [CrossRef]

56. He, Z.; Shankle, M.; Zhang, H.; Way, T.R.; Tewolde, H.; Uchimiya, M. Mineral composition of cottonseed is affected by fertilization management practices. Agron. J. 2013, 105, 341-350. [CrossRef]

57. He, Z.; Zhang, H.; Olk, D.C.; Shankle, M.; Way, T.R.; Tewolde, H. Protein and fiber profiles of cottonseed from upland cotton with different fertilizations. Mod. Appl. Sci. 2014, 8, 97-105. [CrossRef]

58. Bellaloui, N.; Turley, R.B.; Stetina, S.R. Cottonseed protein, oil, and minerals in cotton (Gossypium hirsutum L.) lines differing in curly leaf morphology. Plants 2021, 10, 525. [CrossRef]

59. Bolek, Y.; Tekerek, H.; Hayat, K.; Bardak, A. Screening of cotton genotypes for protein content, oil and fatty acid composition. J. Agri. Sci. 2016, 8, 107-121. [CrossRef]

60. Hu, W.; Dai, Z.; Yang, J.; Snider, J.L.; Wang, S.; Meng, Y.; Wang, Y.; Chen, B.; Zhao, W.; Zhou, Z. Cultivar sensitivity of cotton seed yield to potassium availability is associated with differences in carbohydrate metabolism in the developing embryo. Field Crop. Res. 2017, 214, 301-309. [CrossRef]

61. Han, Y.W. Removal of phytic acid from soybean and cottonseed meals. J. Agric. Food Chem. 1988, 36, 1181-1183. [CrossRef]

62. He, Z.; Zhang, H.; Fang, D.D.; Zeng, L.; Jenkins, J.N.; McCarty, J.C. Effects of inter-species chromosome substitution on cottonseed mineral and protein nutrition profiles. Agron. J. 2020, 112, 3963-3974. [CrossRef]

63. Fageria, N.K.; Baligar, C.; Clark, R.B. Micronutrients in crop production. Adv. Agron. 2002, 77, $185-268$. 
64. He, Z.; Cheng, H.N.; Olanya, O.M.; Uknalis, J.; Zhang, X.; Koplitz, B.D.; He, J. Surface characterization of cottonseed meal products by sem, sem-eds, xrd and xps analysis. J. Mater. Sci. Res. 2018, 7, 28-40. [CrossRef]

65. Peng, Y.; Kyriakopoulou, K.; Ndiaye, M.; Bianeis, M.; Keppler, J.; van der Goot, A. Characteristics of soy protein prepared using an aqueous ethanol washing process. Foods 2021, 10, 2222. [CrossRef]

66. Yatsu, L.; Jacks, T.J.; Kircher, H.W.; Godshall, M.A. Chemical and microscopic studies of the matrix substance in pigment glands of cotton (Gossypium hirsutum L.) seeds. J. Am. Oil Chem. Soc. 1986, 63, 534-537. [CrossRef]

67. Shah, S.; Mahesar, S.A.; Abro, K.A.; Sherazi, S.T.H.; Nizamani, S.M. Ftir characterization and physicochemical evaluation of cottonseed oil. Pak. J. Anal. Environ. Chem. 2017, 18, 46-53. [CrossRef]

68. Abdelrahman, S.A.; Yassin, A.A.; Mirghani, M.E.S.; Bashir, N.H. Determination of gossypol in hamid and bt (seeni 1) cottonseed oil using fourier transform infrared spectroscopy. Borneo J. Pharmacy 2020, 3, 227-234. [CrossRef]

69. Riaz, T.; Iqbal, M.W.; Mahmood, S.; Yasmin, I.; Leghari, A.A.; Rehman, A.; Mushtaq, A.; Ali, K.; Azam, M.; Bilal, M. Cottonseed oil: A review of extraction techniques, physicochemical, functional, and nutritional properties. Crit. Rev. Food Sci. Nutrit. 2021. [CrossRef]

70. Arslan, F.N.; Akin, G.; Elmas, Ş.N.K.; Yilmaz, I.; Janssen, H.-G.; Kenar, A. Rapid detection of authenticity and adulteration of cold pressed black cumin seed oil: A comparative study of atr-ftir spectroscopy and synchronous fluorescence with multivariate data analysis. Food Control 2019, 98, 323-332. [CrossRef]

71. He, Z.; Chapital, D.C.; Cheng, H.N.; Dowd, M.K. Comparison of adhesive properties of water- and phosphate buffer-washed cottonseed meals with cottonseed protein isolate on maple and poplar veneers. Int. J. Adhes. Adhes. 2014, 50, 102-106. [CrossRef]

72. He, Z.; Sleighter, R.L.; Hatcher, P.G.; Liu, S.; Wu, F.; Zou, H.; Olanya, O.M. Molecular level comparison of water extractives of maple and oak with negative and positive ion esi ft-icr mass spectrometry. J. Mass Spectrom. 2019, 54, 655-666. [CrossRef]

73. Ling, T.-R.; Chang, J.-S.; Chiou, Y.-J.; Chern, J.-M.; Chou, T.-C. Characterization of high acid value waste cottonseed oil by temperature programmed pyrolysis in a batch reactor. J. Anal. Appl. Pyrol. 2016, 120, 222-230. [CrossRef]

74. Villalpando, A.; Easson, M.; Cheng, H.; Condon, B. Use of cottonseed protein as a strength additive for nonwoven cotton. Textile Res. J. 2019, 89, 1725-1733. [CrossRef]

75. Swiatkiewicz, S.; Arczewska-Wlosek, A.; Jozefia, D. The use of cottonseed meal as a protein source for poultry: An updated review. World Poultry Sci. J. 2016, 72, 473-484. [CrossRef]

76. Kumar, M. Paruthi paal, a nutrient-rich healthy drink from cottonseed: An indian delicacy. J. Ethnic Foods 2019, 6, 32. [CrossRef]

77. Kumar, M.; Potkule, J.; Patil, S.; Mageshwaran, V.; Radha; Satankar, V.; Berwal, M.K.; Mahapatra, A.; Saxena, S.; Ashtaputre, N.; et al. Evaluation of detoxified cottonseed protein isolate for application as food supplement. Toxin Rev. 2021, 1-8. [CrossRef]

78. Kumar, M.; Potkule, J.; Patil, S.; Saxena, S.; Patil, P.G.; Mageshwaran, V.; Punia, S.; Varghese, E.; Mahapatra, A.; Ashtaputre, N.; et al. Extraction of ultra-low gossypol protein from cottonseed: Characterization based on antioxidant activity, structural morphology and functional group analysis. LWT 2021, 140, 110692. [CrossRef]

79. Venkatesan, H.; Sivamani, S. Cotton seed biodiesel as alternative fuel: Production and its characterization analysis using spectroscopic studies. Inter. J. Renew. Energy Res. 2017, 7, 1333-1339.

80. He, Z.; Guo, M.; Sleighter, R.L.; Zhang, H.; Fortier, C.A.; Hatcher, P.G. Characterization of defatted cottonseed meal-derived pyrolysis bio-oil by ultrahigh resolution electrospray ionization fourier transform ion cyclotron resonance mass spectrometry. $J$. Anal. Appl. Pyrol. 2018, 136, 96-106. [CrossRef]

81. He, Z.; Uchimiya, S.M.; Guo, M. Production and characterization of biochar from agricultural by-products: Overview and use of cotton biomass residues. In Agricultural and Environmental Applications of Biochar: Advances and Barriers; Guo, M., He, Z., Uchimiya, S.M., Eds.; Soil Science Society of America, Inc.: Madison, WI, USA, 2016; pp. 63-86.

82. de Freitas Floriano, R.; Gräbin, K.; Rossi, R.C.; Ferreira, C.D.; Ziegler, V. Impact of roasting conditions on the quality and acceptance of the peanut paste. J. Texture Stud. 2020, 51, 841-848. [CrossRef] [PubMed]

83. Marzocchi, S.; Pasini, F.; Verardo, V.; Ciemniewska-Żytkiewicz, H.; Caboni, M.F.; Romani, S. Effects of different roasting conditions on physical-chemical properties of polish hazelnuts (Corylus avellana L. Var. Kataloński). LWT 2017, 77, 440-448. [CrossRef]

84. Ciemniewska-Żytkiewicz, H.; Bryś, J.; Sujka, K.; Koczoń, P. Assessment of the hazelnuts roasting process by pressure differential scanning calorimetry and mid-ft-ir spectroscopy. Food Anal. Methods 2015, 8, 2465-2473. [CrossRef]

85. Siegmund, B.; Murkovic, M. Changes in chemical composition of pumpkin seeds during the roasting process for production of pumpkin seed oil (part 2: Volatile compounds). Food Chem. 2004, 84, 367-374. [CrossRef]

86. Gorrepati, K.; Balasubramanian, S.; Chandra, P. Plant based butters. J. Food Sci. Technol. 2015, 52, 3965-3976. [CrossRef] [PubMed]

87. He, Z.; Guo, M.; Fortier, C.; Cao, X.; Schmidt-Rohr, K. Fourier transform infrared and solid state ${ }^{13} \mathrm{c}$ nuclear magnetic resonance spectroscopic characterization of defatted cottonseed meal-based biochars. Mod. Appl. Sci. 2021, 15, 108-121. [CrossRef]

88. Zhang, J.; Wedegaertner, T.; Idowu, O.J.; Flynn, R.; Hughs, S.E.; Jones, D.C. Registration of 'numex cot 15 gls'glandless cotton. J. Plant Registr. 2016, 10, 223-227. [CrossRef]

89. Chen, N.; Huang, J.; Li, K. Investigation of a formaldehyde-free cottonseed flour-based adhesive for interior plywood. BioResour. 2020, 15, 5546-5557. [CrossRef]

90. Pettigrew, W.T.; Dowd, M.K. Nitrogen fertility and irrigation effects on cottonseed composition. J. Cotton Sci. 2014, 18, 410-419.

91. McCall, E.R.; Jurgens, J.F. Chemical composition of cotton. Text. Res. J. 1951, 21, 19-21. [CrossRef]

92. He, Z.; Zhang, H.; Olk, D.C. Chemical composition of defatted cottonseed and soy meal products. PLoS ONE 2015, 10, e0129933. [CrossRef] [PubMed] 
93. Pettigrew, W.T.; Dowd, M.K. Varying planting dates or irrigation regimes alters cottonseed composition. Crop Sci. 2011, 51, 2155-2164. [CrossRef]

94. Novotny, L.; Fahey, G.; Layton, B.; Walter, M. Critical factors in determining fiber in feeds and forages. AAFCO's Lab. Methods Serv. Comm. 2017, 1, 1-14.

95. He, Z.; Klasson, K.T.; Wang, D.; Li, N.; Zhang, H.; Zhang, D.; Wedegaertner, T.C. Pilot-scale production of washed cottonseed meal and co-products. Mod. Appl. Sci. 2016, 10, 25-33. [CrossRef] 